\title{
Hand washing compliance among healthcare staff in Intensive Care Unit ( ICU) of a Multispecialty Hospital of North I ndia
}

\author{
Raman Sharma ${ }^{1}$, Meenakshi Sharmaㄹ, Vipin Koushal ${ }^{3}$ \\ 1. Department of Hospital Administration, GMCH, Chandigarh, India. 2. School Of Public Health, PGIMER, Chandigarh, \\ India. 3. Department of Hospital Administration, $\mathrm{GMCH}$, Chandigarh, India
}

Correspondence: Raman Sharma. Address: Department of Hospital Administration, Government Medical College \& Hospital, Chandigarh 160012, India. E-mail: drramansharmamha@rediffmail.com

Received: May 9, 2012

Accepted: August 29, 2012

Published: December 1, 2012

DOI : 10.5430/jha.v1n2p27

URL: http://dx.doi.org/10.5430/jha.v1n2p27

\section{Abstract}

Introduction: Hand hygiene is the single most important strategy to prevent HAIs. The present cross sectional study was conducted in ICUs to assess the hand washing practices being followed among health care workers and the factors that motivate or inhibit hand washing.

Results: During two week analysis, 2400 hand washing opportunities were observed. Hand washing adherence rate was 86.0\%, with highest compliance among nurses (94.0\%). Compliance was (95.0\%) after patient contact than 72.5\% before contact. More than $90.0 \%$ staff was aware about facts viz. diseases prevented by hand washing (96.2\%), ideal duration of hand washing (92.6\%), reduction of HAI with hand washing (98.0\%) etc. Reasons for non-adherence emerged as work pressure (94.2\%) and unavailability of materials (82.4\%).

Conclusion: The level of compliance (86\%) is below the need to be there in ICU otherwise. Easy access to hand-rub solutions, adherence measurement and institutional commitment might contribute to staff sensitivity to hand hygiene practices.

\section{Key words}

Hand washing, Compliance, Intensive care unit, Direct observation, Product utilization, Questionnaire

\section{Introduction}

Hand hygiene is the single most important element of strategies to prevent Health Care-Associated Infection (HCAI) ${ }^{[1,2,3]}$. With the emergence of antibiotic-resistant organisms, the importance of hand hygiene within hospitals has re-emerged as a priority for the 21st century hospital administrators.

Every patient reporting to the hospital is potentially at risk of contracting hand-transmitted infections. Especially vulnerable groups include pregnant women, children, old people, and those with weakened immune systems. Still, Hand washing in hospitals is not given due emphasis by doctors, nurses and other health care staff. To assess this issue updated 
guidelines intended to stimulate improvement in hand hygiene practices have been developed ${ }^{[4]}$. Along with it various tools and methodologies have been developed for hand hygiene measurement.

Direct observation of the hand hygiene behavior of health care workers is considered the "Gold Standard" "5]. It provides quantitative and qualitative information about when and why failures in hand hygiene occur and distinguish between hand hygiene practiced by different types of health care workers and patients or family members. Though it is a labor intensive and costly method ${ }^{[6]}$ and requires uniformity in the selection and training of observers and in the recording of data ${ }^{[6,7]}$, it can change the behavior of staff members if they are aware that they are being observed ${ }^{[6,7]}$.

Product measurement is considered an indirect approach to assessing adherence to hand hygiene guidelines and the frequency of hand hygiene performance ${ }^{[8,9]}$. Some studies ${ }^{[10,11]}$ have reported that product measurement is more sensitive to changes in hand hygiene behavior than is observation. Pittet et al. measured product use as part of a hand hygiene intervention ${ }^{[12,13]}$.

Surveying health care workers, patients, and family members is another indirect method of assessing aspects of hand hygiene adherence. Surveys can measure a range of hand hygiene components that cannot be measured by observation and product measurement viz. Staff knowledge, attitudes, and beliefs, perceptions of their own behavior and structural issues, such as the availability of hand hygiene products, product accessibility. Also surveys are helpful in learning what health care workers know and think and why health care workers adhere (or do not adhere) to hand hygiene guidelines.

These hand washing tools and methodologies have been used differently over the years. To overcome the gaps and discrepancies of various methods practices, in 2005, WHO launched Global Patient Safety Challenge under the slogan of "Clean care is safer care". A major component of the challenge is to evaluate and implement the guidelines for the promotion of hand hygiene in health care. It involves Member Nations for strengthening their capacity to improve patient safety, share experiences and to explore aspects that may influence its promotion among healthcare workers ${ }^{[14]}$.

In a study by Marra et al. ${ }^{[27]}$ using the observational methods, product use methods and electronic surveillance, the overall rate of hand hygiene adherence was found to be $62.3 \%$ (there were 2,249 opportunities for hand hygiene observed, and representing 1,402 cleansing episodes). Similarly, in a multi hospital study in Poland ${ }^{[28]}$, nearly all (95.6\%) hospitals had a written protocol for hand washing procedures, but according to the findings of study team, the compliance rates varied from 20 to $80 \%$, although in most institutions was between $40 \%$ and $60 \%$. The adherence rate in a twenty-four-hour observational study of hospital hand hygiene compliance by Randle J et al. ${ }^{[29]}$ it was found that out of a total of 823 hand hygiene opportunities (HCWs, $\mathrm{N}=659$; patients and visitors, $\mathrm{N}=164$ ), compliance was $47 \%$ for doctors, $75 \%$ for nurses, $78 \%$ for allied health professionals, and 59\% for ancillary and other staff $(P<.001)$.

Also, it is proven fact that, organisms that cause nosocomial infections are most commonly transmitted by the hands of healthcare workers ${ }^{[4]}$. Therefore, hand-hygiene is considered to be the single best measure for infection control and it has been observed that rates of nosocomial infection are considerably reduced when healthcare workers act in accordance with recommended guidelines for hand hygiene ${ }^{[4-6]}$. Despite this fact, physicians' adherence to hand-hygiene practices remains consistently poor ${ }^{[6-8]}$. Notable factors for poor compliance include hand irritation ${ }^{[9]}$, inaccessibility or shortage of hand-washing equipment ${ }^{[7-11]}$, dense working conditions ${ }^{[9,10,12]}$ and poor knowledge ${ }^{[8,10]}$.

The present study is also an attempt to fulfill the afore mentioned statement by providing useful insight into the prevailing practices of hand-hygiene and points out major obstacles in health care setting. Such sort of studies are lacking in India. So, the present study was planned to assess the knowledge and practices being followed among health care workers and to assess the factors that motivate, facilitate, hinder or inhibit hand washing. 


\section{Methodology}

Government Medical College and hospital (GMCH), Chandigarh is a tertiary level multispecialty teaching hospital providing care to the residents of Chandigarh and the surrounding states. It is a 696 bedded hospital with an annual OPD of 4.5 lakhs and IPD of about 40,000. The hospital has two ICUs (Closed type ICU under anesthesia department), with a total of 18 beds. Both ICUs have conveniently located hand washing facilities.

It was a cross sectional study and whole of the ICU staff (64 health care members viz. clinicians, nurses and other paramedical staff) was taken as sample size. In a two week analysis, each ICU was visited for a week. The observer recorded all potential opportunities for hand hygiene in ICUs.

Adherence to hand washing was assessed using three methods i.e. Direct observation, Product utilization and Survey. This method was specifically chosen and the same was updated by Joint Commission (JCI) ${ }^{[15]}$ in collaboration with The Association for Professionals in Infection Control, Epidemiology Inc., Centers for Disease Control and Prevention (CDC), the Institute for Healthcare Improvement (IHI), the National Foundation for Infectious Diseases, the Society for Healthcare Epidemiology of America and World Health Organization World Alliance for Patient Safety (WHO WAPS).

Table 1. Direct Observation method for measuring hand washing adherence rate

\begin{tabular}{|c|c|c|c|}
\hline S.NO. & Observations & Opportunities & Adherence rate \\
\hline 1 & $\begin{array}{l}\text { Number of observed hand hygiene actions } \\
\text { before patient contact }\end{array}$ & $\begin{array}{l}\text { Number of hand hygiene opportunities } \\
\text { before patient contact }\end{array}$ & \multirow{6}{*}{$\begin{array}{l}\text { Observations (A)/ } \\
\text { Opportunities (B) } \\
* 100\end{array}$} \\
\hline 2 & $\begin{array}{l}\text { Number of observed hand hygiene actions } \\
\text { before aseptic task }\end{array}$ & $\begin{array}{l}\text { Number of hand hygiene opportunities } \\
\text { before aseptic task }\end{array}$ & \\
\hline 3 & $\begin{array}{l}\text { Number of observed hand hygiene actions } \\
\text { after body fluid exposure risk }\end{array}$ & $\begin{array}{l}\text { Number of hand hygiene opportunities after } \\
\text { body fluid exposure risk }\end{array}$ & \\
\hline 4 & $\begin{array}{l}\text { Number of observed hand hygiene actions } \\
\text { after patient contact }\end{array}$ & $\begin{array}{l}\text { Number of hand hygiene opportunities after } \\
\text { patient contact }\end{array}$ & \\
\hline 5 & $\begin{array}{l}\text { Number of observed hand hygiene actions } \\
\text { after contact with patient surroundings }\end{array}$ & $\begin{array}{l}\text { Number of hand hygiene opportunities after } \\
\text { contact with patient surroundings }\end{array}$ & \\
\hline Total & A & B & \\
\hline
\end{tabular}

Direct observation involved observing 200 opportunities per day. The observer visited the ICU on daily basis from 08:00AM till 200 observations are complete. The observations were noted both before and after the patient contact. This procedure was followed for a week (6 days) in each ICU. Averages for these were taken to calculate the adherence rate (the action is compared with the opportunity) as in Table 1.

The product utilization (liquid soap \& alcohol based solution) was noted from the stock registers/record books of the materials issued/indented in the wards. It was found that one soap cake (120 gm.) is worth for 40 hand washings, while liquid alcohol rub is worth for 334 (approx.) hand washings/bottle (500 mL). The purchase done by staff was also taken into account. A check was kept on pilferage by daily noting stocks. The adherence to hand washing with product utilization was calculated as in Table 2.

A survey was also done by filling a pre-tested close ended validated questionnaire. Enveloped questionnaire was given to each health care staff and was asked to return it next day. The questionnaire was pertaining to intentions of adherence to hand hygiene, perception and knowledge, opportunities, steps, actions and attitude towards hand hygiene. It also involved the facts about difficulty of adhering to hand hygiene; risk of cross transmission of infections linked to non-adherence to hand hygiene. 
Table 2. Product utilization method for measuring hand washing adherence

\begin{tabular}{ll}
\hline Parameters & Method of assessment \\
\hline Number of indications for hand & 1. Directly observed personnel (200 indications) \\
& $\begin{array}{l}\text { 2. Divide the total number of indications by total time observed to obtain mean number of hand } \\
\text { hygiene /hours } \\
\text { 3. Multiply value obtains in step } 2 \text { by } 24 \text { to get mean number indications/day. } \\
\text { 4. Obtain the patient census for period observations were made. } \\
\text { 5. Calculate the mean number of indications for hand hygiene/day/patient by dividing mean } \\
\text { number of indications/day by census value }\end{array}$ \\
$\begin{array}{ll}\text { Number of hand hygiene actual } \\
\text { episode }\end{array}$ & $\begin{array}{l}\text { 2. Obtain data on volume of hand hygiene products used per month (soap/alcohol) } \\
\text { Compute number of indications/month by multiplying indications for hand hygiene/day/patient } \\
\text { by number of days in the month by mean monthly patient census. } \\
\text { Obtain a hand hygiene adherence rate by dividing the total number of hits by total number of } \\
\text { indications for that month. }\end{array}$ \\
\hline
\end{tabular}

\section{Results}

During two week (12 days) analysis in ICU, twenty four hundred (2400) hand washing opportunities were observed. Among 64 healthcare workers, 18 (28.1\%) were physicians (including interns, residents), 34 (53.2\%) nurses and 12 (18.7\%) other health care workers (including technicians, physiotherapists (Table 3).

Table 3. Compliance rate for hand washing on Direct Observation method

\begin{tabular}{lllllll}
\hline Health care worker & \multicolumn{2}{l}{ Number of subjects } & \multicolumn{2}{l}{ Opportunities of hand washing } & \multicolumn{2}{l}{ Compliance (\%) } \\
\hline & $\mathrm{n}$ & $\%$ & $\mathrm{n}$ & $\%$ & $\mathrm{n}$ & $\%$ \\
Physicians & 18 & 28.1 & 524 & 21.8 & 452 & 86.2 \\
Nurses & 34 & 53.2 & 1472 & 61.4 & 1384 & 94.0 \\
Others & 12 & 18.8 & 404 & 16.8 & 308 & 76.2 \\
\hline
\end{tabular}

Table 4. Compliance rate for hand washing on product utilization method

\begin{tabular}{lll}
\hline Parameters & Steps of assessment & ICU \\
\hline Number of indications for hand & Directly observed personnel (200 indications/time in hours) & $216 / 6$ \\
hygiene & Mean number of hand hygiene/hour & 36 \\
& Mean number indications/day & 864 \\
& Census for observation period & 16 \\
& Mean number of indications for hand hygiene/day/patient & 54 \\
& Number of hand hygiene indications/month & 25,920 \\
Number of hand hygiene actual & Volume of hand hygiene products used per month (soap/alcohol) & 88 soaps \& 56 liquid \\
episode & alc. rub bottles & 22,213 \\
& Number of hand hygiene indications/Actual hand hygiene & $85.69 \%$ \\
\hline
\end{tabular}


Out of the total opportunities, nurses had the highest number of contacts (61.4\%) followed by doctors (21.8\%), and allied health workers (16.8\%), which contributed to a small percentage of total hand hygiene opportunities. The average compliance with hand washing was around $86.0 \%$ (Table $3 \&$ Table 4 ), which differed significantly among professional health care workers with higher compliance among nurses (94.0\%), followed by physicians (86.2\%) and least by other health care staff (76.2\%). Out of the total physicians, residents and interns mostly washed their hands only after making patient contact. Out of the average compliance of $86 \%$ hand washing, the more number of hand washing opportunities (95.0\%) were after patient contact, while it was $72.5 \%$ before patient contact. Hand washing was done with alcohol in $96.04 \%$ of instances and it was with soap in $3.96 \%$ of instances. The average number of contacts per patient per hour was 11.

On survey method, it was found that more than $90.0 \%$ of the health care staff was aware about hand washing facts viz. diseases prevented by hand washing (96.2\%), type of dirt tackled by hand washing (94.8\%), ideal duration of hand washing (92.6\%) and the extent of reduction of HAI by hand washing properly (98.0\%). On the other end, reasons for non-adherence emerged as unavailability of soap at the washing area (82.4\%) and work load pressure (94.2\%).

\section{Discussion}

The present study was conducted to assess the Hand washing compliance among Healthcare Workers in Intensive Care Unit (ICU) of a Multispecialty Hospital. Such studies have not been done previously which has examined healthcare workers' hand-cleaning knowledge and practices and factors that motivate and inhibit hand washing. Like other studies ${ }^{[16-18]}$, this study has also revealed low baseline rate (86.0\%) of hand washing compliance by health care workers especially in ICUs.

Physicians freely acknowledge that hand washing is an important tool in the control of nosocomial infection, but complains it's also repetitive and dull ${ }^{[19-20]}$. There are a number of known factors affecting compliance with hand hygiene such as lack of time, high patient workload, patients' need taking priority, forgetfulness, lack of knowledge of importance of hand hygiene in preventing cross Infection, poor access to hand washing facilities, lack of institutional commitment and skin irritation to hand hygiene products ${ }^{[21-23]}$. In the present study, the main barriers to regular hand hygiene in descending order were lack of time, high patient workload, lack of knowledge of importance of hand hygiene in preventing cross Infection, lack of institutional commitment. Fortunately, respondents in this study believed that hand irritation was not a major element causing poor compliance; as opposed to other studies wherein hand irritation associated with hand-rub use was described as the most prominent barrier ${ }^{[21]}$.

Like other investigators ${ }^{[24]}$, we observed better hand washing compliance among nurses as compared to other health care workers. In our study, it was found that health care workers had the practice of washing hands after patient care, and similar sort of variations were demonstrated for hand washing among health care workers in the studies of Maydon et al. ${ }^{[25]}$ and Credon et al. ${ }^{[26]}$ This disparity might be explained by possible explanation; the desire on the part of healthcare workers to protect themselves from transmissible pathogens.

\section{Conclusion}

We found out that the average level of compliance with recommended hand washing practices among health care workers was $86 \%$, which is below the need of to be there in ICU otherwise. Although the hand hygiene procedure is simple, its application is a complex phenomenon that is not easily explained or changed. Easy access to hand-rub solutions, adherence measurement and performance feedback as well as institutional commitment to hand hygiene promotion as a priority for patient safety, might contribute to health care staff sensitivity to hand hygiene. All future interventions must be supported by improving the facilities for hand-hygiene. 


\section{References}

[1] Pittet D, Boyce J.M. Hand hygiene and patient care: pursuing the Semmelweis legacy. Lancet Infect Dis. 2001 April; 9-20. http://dx.doi.org/10.1016/S1473-3099(09)70295-6

[2] WHO guidelines for hand hygiene in health care, Geneva, Switzerland: World Health Organization. 2009.

[3] AllegranziB, PittetD. The role of hand hygiene in health care-associated infection prevention. J Hosp Infect. 2009 Aug; 29. PMid:19720430 http://dx.doi.org/10.1016/j.jhin.2009.04.019

[4] Boyce J.M., Pittet D.: Guideline for Hand Hygiene In HealthCare Settings: Recommendations of the Healthcare Infection Control Practices Advisory Committee and the HICPAC/SHEA/ APIC/ IDSA Hand Hygiene Task Force. Infect Control Hosp Epidemiol. 2002 Dec.; 23(Suppl.): S3-S40. PMid:12515399 http://dx.doi.org/10.1086/503164

[5] World Health Organization (WHO): WHO Guidelines on Hand Hygiene in Health Care (Advanced Draft): A Summary. Geneva, Switzerland: WHO, 2006.

[6] Haas J.P., Larson E.L.: Measurement of compliance with hand hygiene. J Hosp Infect. 2007 May; 66: 6-14. PMid:17276546 http://dx.doi.org/10.1016/j.jhin.2006.11.013

[7] Gould D.J., et al.: Measuring hand washing performance in health service audits and research studies. J Hosp Infect. 2007 Jun.; 66: 109-115. PMid:17433491 http://dx.doi.org/10.1016/j.jhin.2007.02.009

[8] Haas J.P., Larson E.L.: Measurement of compliance with hand hygiene. J Hosp Infect. 2007 May; 66: 6-14. PMid:17276546 http://dx.doi.org/10.1016/j.jhin.2006.11.013

[9] World Health Organization (WHO): WHO Guidelines on Hand Hygiene in Health Care (Advanced Draft): A Summary. Geneva, Switzerland: WHO, 2006.

[10] Van de Mortel T., Murgo M.: An examination of covert observation and solution audit as tools to measure the success of hand hygiene interventions. Am J Infect Control. 2006; 34(3): 95-99. PMid:16630970 http://dx.doi.org/10.1016/j.ajic.2005.07.006

[11] Aragon D., Sole M.L., Brown S.: Outcomes of an infection prevention project focusing on hand hygiene and isolation practices. AACN Clinical Issues. 2005 Apr.-Jun.; 16: 121-132. http://dx.doi.org/10.1097/00044067-200504000-00002

[12] Pittet D., et al.: Effectiveness of a hospital-wide programme to improve compliance with hand hygiene. Lancet. 2000 Oct.; 356:1307-1312. Errata in Lancet. 2000 Dec. 23-30; 356: 2196.

[13] Pittet D., et al.: Cost implications of successful hand hygiene promotion. Infect Control Hosp Epidemiol. 2004 Mar.; 25: $264-266$. PMid:15061421 http://dx.doi.org/10.1086/502389

[14] World Health Organization. Clean Care is Safer Care: Countries and regions committing to support health care-associated infection [Internet]. 2009 (Cited 2009 Feb 20). Available from: http://www.who.int/gpsc/statements/en/index.html.

[15] World Health Organization (WHO), World Alliance for Patient Safety: Manual for Observers. Geneva, Switzerland: WHO, 2006.

[16] Doebbeling BN, Stanley GL, Sheertz CT, et al. Comparative efficacy of alternative hand-washing agents in reducing nosocomial infections in intensive care units. N Engl J Med. 1992; 327: 88-93. PMid:1285746 http://dx.doi.org/10.1056/NEJM199207093270205

[17] Lund S, Jackson J, Leggett J, Hales L, Dworkin R, Gilbert D. Reality of glove use and hand washing in a community hospital. AmJInfectControl. 1994; 22: 352-357. http://dx.doi.org/10.1016/0196-6553(94)90034-5

[18] Albert RK, Condie F. Hand-washing patterns in medical intensive-care units. N Engl J Med. 1981; 304: 1465-1466. PMid:7248048 http://dx.doi.org/10.1056/NEJM198106113042404

[19] Meengs MR, Giles BK, Chisholm CD, Cordell WH, Nelson DR. Hand washing frequency in an emergency department. Ann Emerg Med. 1994; 23(6): 1307-12. http://dx.doi.org/10.1016/S0196-0644(94)70357-4

[20] Boyce JM, Pittet D. Guideline for Hand Hygiene in Health-Care Settings. Recommendations of the Healthcare Infection Control Practices Advisory Committee and the HICPAC/SHEA/APIC/IDSA Hand Hygiene Task Force. Society for Healthcare Epidemiology of America/Association for Professionals in Infection Control/Infectious Diseases Society of America. MMWR Recomm Rep. 2002; 51 (RR-16): 1-45.

[21] Voss A, Widmer AF. No time for handwashing!!? Handwashing versus alcoholic rub: can we afford 100\% compliance? Infect Control Hosp Epidemiol. 1997; 18(3): 205-8. PMid:9090551 http://dx.doi.org/10.1086/647590

[22] Patarakul K, Tan-Khum A, Kanha S, Padungpean D, Jaichaiyapum OO. Cross-sectional survey of hand-hygiene compliance and attitudes of health care workers and visitors in the intensive care units at King Chulalongkorn Memorial Hospital. J Med Assoc Thai. 2005; 88 Suppl 4: S287-93. PMid:16623043

[23] Barrett R, Randle J. Hand hygiene practices: nursing students' perceptions. J Clin Nurs. 2008; 17(14): 1851-7. PMid:18578759 http://dx.doi.org/10.1111/j.1365-2702.2007.02215.x

[24] Mayon White RT, Ducel G, Kereselidze T, Tikomirov E. An international survey of the prevalence of hospitalacquired infection. J Hosp Infect. 1988; 11 (Suppl A): 43-48. http://dx.doi.org/10.1016/0195-6701(88)90164-8 
[25] Creedon SA. Healthcare workers' hand decontamination practices: compliance with recommended guidelines. J Adv Nurs. 2005; 51: 208-16. PMid:16033588 http://dx.doi.org/10.1111/j.1365-2648.2005.03490.x

[26] Wendt C, Knautz D, von Baum H. Differences in hand hygiene behavior related to the contamination risk of healthcare activities in different groups of healthcare workers. Infect Control Hosp Epidemiol. 2004; 25: 203-6. PMid:15061410 http://dx.doi.org/10.1086/502378

[27] Marra AR, Moura DF Jr, Paes AT, dos Santos OF, Edmond MB. Measuring rates of hand hygiene adherence in the intensive care setting: a comparative study of direct observation, product usage, and electronic counting devices. Infect Control Hosp Epidemiol. 2010 Aug; 31(8): 796-801. PMid:20565261 http://dx.doi.org/10.1086/653999

[28] Heczko PB, Kleszcz P. Handwashing practices in Polish hospitals: results of a survey conducted by Polish Society of Hospital Infection. J Hosp Infect. 2001 Aug; 48 Suppl A: S47-9.

[29] Randle J, Arthur A, Vaughan N. Twenty-four-hour observational study of hospital hand hygiene compliance. J Hosp Infect. 2010 Nov; 76(3): 252-5. Epub 2010 Sep 20. PMid:20850899 http://dx.doi.org/10.1016/j.jhin.2010.06.027 